\title{
Induction and Subculture of Bud Forming Tissues from Twig Sections of Chamaecyparis pisifera, var. filifera
}

\author{
Tomosaburo Yokoyama*, Masayosi Arai and Masayuki Takeuchr \\ Department of Regulation Biology, Saitama University \\ 338, Simookubo, Urawa, Saitama, Japan \\ (Received April 26, 1988) \\ (Accepted January 19, 1989)
}

\begin{abstract}
Callus with multiple buds (CMB) consisting of callus and many buds in which the multiplication of buds was associated with callus growth was induced from the sections of twigs on an agar medium in an ornamental conifer, Chamaecyparis pisifera, var. finifera Beissn. A devised medium containing half strength of Murashige and Skoog's minerals, vitamins, inositol, amino acids, sucrose, $1 \mathrm{mg} / l \mathrm{BA}$ and $0.3 \mathrm{mg} / l$ IAA (SF-medium) was favored to induce CMB. CMB is able to be subcultured on SF-medium without a decrease in capacity to form buds for more than 5 years. Buds in various developmental stages were observed in $\mathrm{CMB}$ depending on the length of culture period. Buds with scale-like leaves in CMB were observed in the regular subculture cycle. Needle leaves appeared in the buds of CMB with prolonged culture more than about 2 months on SF-medium without regular subculture. Buds developed into shoots when buds were isolated from $\mathrm{CMB}$ and cultured on SF-medium with low concentration of NAA or IBA, 0.03-0.1 mg/l.
\end{abstract}

Organ formation in in vitro culture of gymnosperms was observed in various isolated organs such as cotyledons, ${ }^{1,2)}$ embryos $^{3-7)}$, hypocotyls,$^{8)}$ needles ${ }^{9,10)}$ and vegetative buds ${ }^{11)}$ in several species. Those experiment were observed in primary culture, whereas organ formation in the callus culture was marely observed in Sequoia sempervirens. ${ }^{12)}$ Tissue cultures which consisted of callus like mass containing embryoids were recently induced from isolated embryos in Picea, ${ }^{13,14)}$ which were subcultured and regenerated organs such as embryos.

In this experiment, we induced bud forming tissue from twigs of an ornamental conifer tree, Chamaecyparis pisifera, var. filifera Beissn. in which callus growth was associated with the multiplication of buds (CMB), and $\mathrm{CMB}$ was subcultured for many passages without a decrease in the growth rate and bud multiplication.

\section{Materials and Methods}

Twigs used in this experiment as starting materials were collected in early August from a tree of Chamaecyparis pisifera Sieb. et. Zucc. var. filifera Beissn. et Hochst. which tree was established by planting a cutting about 30 years ago and grew up in a garden in Saitama prefecture, Japan. Collected twigs were surface-sterilized with $3 \%$ sodium hypochlorite for $15 \mathrm{~min}$ and rinsed with sterilized distilled water for several times, and then cut into sections $(5 \mathrm{~mm}$ long). Twig segments were placed horizontally on agar medium and cultured under continuous light $(3,000$ lux $)$ at $27 \pm 1^{\circ} \mathrm{C}$.

Basal medium was made up of half strength of Murashige and Skoog's minerals, ${ }^{15)} 1 \mathrm{mg} / \mathrm{l}$ thiamine $\mathrm{HCl}, 1 \mathrm{mg} / \mathrm{l}$ pyridoxine $\mathrm{HCl}, 4 \mathrm{mg} / \mathrm{l}$ nicotinic acid, $0.1 \mathrm{mg} / \mathrm{l}$ biotin, $100 \mathrm{mg} / \mathrm{l}$ inositol, $2 \%$ sucrose. An amino acids mixture contained $2 \mathrm{mg} / \mathrm{l}$ each of L-alanine, L-valine L-isoleucine, L-leucine, L-serine, L-

* Present address : Saitama Children's Zoo, Iwadono 554, Higashimatsuyama 355, Saitama, Japan. 
Table 1. Morphogenetic response of twig sections to various media containing $1 \mathrm{mg} / l \mathrm{BA}$ and $0.3 \mathrm{mg} / l \mathrm{IAA}$.

\begin{tabular}{ll}
\hline \multicolumn{1}{c}{ Basal medium } & \multicolumn{1}{c}{ Responses } \\
\hline $\mathrm{BM}$ & 2 or 3 buds sprouted $(90 \%)$ and no response $(10 \%)$ \\
$\mathrm{BM}+$ amino acids (SF-medium) & 2 or 3 buds sprouted $(43 \%)$ and CMB induction (57\%) \\
$2 \mathrm{BM}$ & 2 or 3 buds sprouted $(88 \%)$ and no response $(12 \%)$ \\
$2 \mathrm{BM}+$ amino acids & 2 or 3 buds sprouted $(91 \%)$ and no response $(9 \%)$ \\
\hline
\end{tabular}

BM represents a half stength of Murashige and Skoog's minerals, and 2 BM represents full strength of Murashige and Skoog's minerals. Each medium contained vitamins and 2\% sucrose described in Materials and Methods. Values in the response show the average of three replicates. Twenty sections were used in each experiment.

threonine, L-proline, L-tryptophane, L-aspartic acid, L-glutamic acid, L-glutamine, L-methionine, L-phenylalanine, L-tyrosine, and L-histidine and $5 \mathrm{mg} / \mathrm{l}$ glycine. Various concentrations of BA and IAA were added to the basal medium. The $\mathrm{pH}$ of the medium was adjusted to $5.7-5.8$ with $1 \mathrm{~N} \mathrm{NaOH}$ or $1 \mathrm{~N}$ $\mathrm{HCl}$, and $7 \mathrm{~g} / \mathrm{l}$ agar was added to each medium and dissolved in water bath. A $20 \mathrm{ml}$ of medium was dispensed to $50 \mathrm{ml}$ Erlenmeyer flask, and autoclaved at $121 \pm 1^{\circ} \mathrm{C}$ for $15 \mathrm{~min}$.

Full strength of Murashige and Skoog's minerals was also used in combination with vitamins, amino acids and various concentrations of BA and IAA as a control experiment.

\section{Result}

Induction and subculture of the callus with multiple buds (CMB) from the twig sections

Twig sections were cultured on the agar media containing $1 \mathrm{mg} / l \mathrm{BA}$ and $0.3 \mathrm{mg} / /$ IAA (Table 1 ). $\mathrm{CMB}$ was initiated only on the basal medium with amino acids (SF-medium) (Fig. 1). Two or three buds sprouted in the sections on the media other than SF-medium. CMB was green and friable, and contained many bud primordia. After a month from the inoculation, CMB grown up was divided into small pieces (Fig. 2), which were transferred to several different media described in Table 1. Vigorous growth of $\mathrm{CMB}$ was observed only on SF-medium (Fig. 3). After determination of suitable medium for subculture, CMB was regularly subcultured on SF-medium every month for more than about 5 years without decrease in both the growth rate and multiplication of bud primordia.

Twig sections were cultured on SF-medium containing various concentrations of BA and IAA in order to know the optimum concentrations for $\mathrm{CMB}$ induction. $\mathrm{CMB}$ was induced only on $1 \mathrm{mg} / \mathrm{l} \mathrm{BA}$ and $0.3 \mathrm{mg} / \mathrm{l}$ IAA (Table 2). Two or three buds have sprouted from the sections on the medium containing $1 \mathrm{mg} / \mathrm{l} \mathrm{BA}$. On the other hand, on the medium containing $1 \mathrm{mg} / / \mathrm{or} 3 \mathrm{mg} / \mathrm{l}$ IAA bud sprouting was inhibited and the callus without bud primordia formed.

\section{Various developmental stages of buds from $C M B$}

Various developmental stages of buds were observed in $\mathrm{CMB}$ depending on the culture period on $\mathrm{SF}$-medium. Bud primordia were scattered on the surface of $\mathrm{CMB}$ on $\mathrm{SF}$-medium in regular subculture cycle (Figs. 2, 4). Scale-like leaves appeared in the bud of CMB shorter than 2 month on SF-medium without subculture (Figs. 5, 6). Needle leaves appeared in buds of CMB longer than 2 months on SF-medium without subculture (Figs. 6, 7). $\mathrm{CMB}$ as shown in Fig. 7 was cultured on SF-medium for about 3 months. Further development of buds isolated from CMB was succeeded on SF-medium containing low concentrations of IBA or NAA $(0.03-0.1 \mathrm{mg} / l)($ Fig. 8)

\section{Discussion}

$\mathrm{CMB}$ in this experiment closely related to callus with buds induced from excised embryos of Sitka spruce (Picea sitchensis (Bong.) CARr.) ${ }^{16:}$ and to meristematic nodule of J. Aitken-Christie in Pinus radiata (cited from Agricell Rep., 9 (2), 1987). Tanaka and Ikeda has also established a multiplica- 


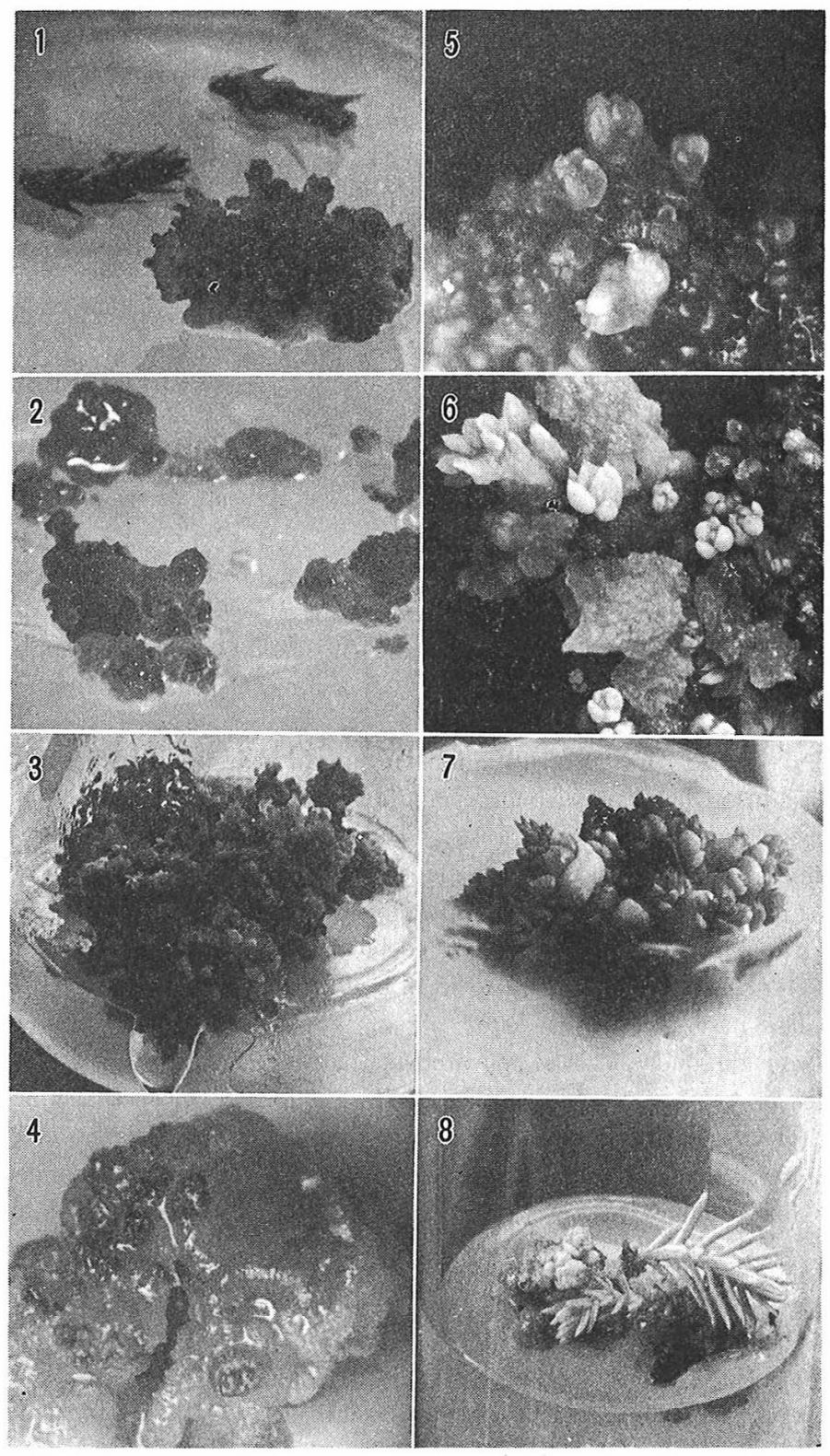

Fig. 1. Induction of $\mathrm{CMB}$ from the twig sections on SF-medium. Sections were cultured for about one month.

Fig. 2. The initial stage of CMB pieces which had been transferred to fresh SF-medium.

Fig. 3. $\mathrm{CMB}$ which had been cultured on SF-medium for 45 days without regular subculture.

Fig. 4. Surface structure of $\mathrm{CMB}$ in regular subculture cycle. Many bud primordia were scattered over the surface region.

Fig. 5. Bud primordia developed further on CMB cultured on SF-medium for about 2 month without regular subculture.

Fig. 6. Bud primordia on $\mathrm{CMB}$ cultured for 2 month without regular subculture. Both types of leaves were observed on the bud primordia.

Fig. 7. Buds with needle leaves sprouted among scale-like leaves on CMB cultured on SF-medium for 3 months without regular subculture.

Fig. 8. Shoots which developed from bud primordia isolated from CMB were cultured on SF-medium containing $0.03 \mathrm{mg} / \mathrm{l}$ IBA for about 3 months. Needle leaves were observed. 
Table 2. Morphogenetic response of the sections on SF-medium containing various concentrations of BA and IAA.

\begin{tabular}{|c|c|c|}
\hline $\mathrm{BA}(\mathrm{mg} / \mathrm{l})$ & IAA $(\mathrm{mg} / l)$ & Response \\
\hline 0 & 0 & no response \\
\hline 1 & 0 & 2 or 3 buds sprouted $(85 \%)$ and no response $(15 \%)$ \\
\hline 1 & 0.03 & 2 or 3 buds sprouted $(95 \%)$ and no response $(5 \%)$ \\
\hline 1 & 0.1 & $\begin{array}{l}2 \text { or } 3 \text { buds sprouted (35\%), induction of a small amount of CMB ( } 47 \%) \\
\text { and no response }(18 \%)\end{array}$ \\
\hline 1 & 0.3 & $\begin{array}{l}2 \text { or } 3 \text { buds sprouted }(38 \%) \text {, remarkable induction of } \mathrm{CMB}(53 \%) \text { and no } \\
\text { response }(9 \%)\end{array}$ \\
\hline 1 & 1 & $\begin{array}{l}\text { remarkable callus induction with } 2 \text { or } 3 \text { buds sprouted }(95 \%) \text { and no } \\
\text { response }(5 \%)\end{array}$ \\
\hline 1 & 3 & remarkable callus $(82 \%)$ and no response $(18 \%)$ \\
\hline
\end{tabular}

Values in response show average of three replicates. Twenty sections were used in each experiment.

tion system of buds in a herbaceous plants by using the Shoot Primordia Culture method on the media containing particular combinations of plant growth regulators. ${ }^{17)} \mathrm{CMB}$ is a strong tool for micropropagation of Chamaecyparis pisifera var. filifera and SF-medium might be applicable to some other ornamental conifers included in a genus Chamaecyparis for the clonal propagation starting from the adult plant of particular genotype.

Stability of CMB about growth and of initiation of buds from it was outstanding in comparison with many angiospermal callus. The rate in bud formation in callus culture gradually decreased according to the progress of the subculture in general cases. For instance, bud formation in carrot callus culture completely disappeared after 38 passages, ${ }^{18)}$ and bud formation in tobacco callus culture showed a great decline in the rate of bud formation in the third year from the isolation. ${ }^{19)}$ Japanese persimmon callus which was induced from immature embryos formed buds after the second subculture but ceased after the third subculture. ${ }^{20}$ CMB has continued to form buds for even 5 years after its isolation without a distinguishable decrease in multiplication rate.

Scale-like leaves from the buds of CMB appeared in the regular subculture cycle or during prolonged culture for 2 months on SF-medium. Needle leaves were formed in shoots which developed on SFmedium containing IBA or NAA. Needle leaves are only observed in early developmental stages of the ontogeny in C. pisifera and scarcely appear in C. pisifera var. filifera under natural conditions. Therfore, in vitro formation of needle leaves may suggest the occurrence of atavism in the CMB culture system.

\section{References}

1) Konar, R. N., Y.P. Oberoi, 1965. Phytomorphology, 15: 137-140.

2) David, A., H. David, T. Mateille, 1982. Physiol. Plant., 56 : 102-107.

3) Cheng, T. Y., 1975. Plant Sci., 5: 97-102.

4) Sommer, H. E., C. L. Brown, P. P. Kormanik, 1975. Bot. Gaz., 136 : 196-200.

5) Arnold, S. V., T. Eriksson, 1978. Physiol. Plant., 44 : 283-287.

6) Minocha, S., 1978. Can. J. Bot., 58: 366-370.

7) Arnold, S. V., T. Eriksson, 1981. Can. J. Bot., 59 : 870-874.

8) Isikawa, H., 1974. Bot. Mag., $87: 73-77$.

9) Arnold, S. V., T. Eriksson, 1979. Plant Sci. Lett., $15: 363-372$.

10) Jansson, E., C. H. Bornman, 1980. Physiol. Plant., 49 : 105-111.

11) Arnold, S. V., T. Eriksson, 1979. Physiol. Plant., 45 : 29-34.

12) Ball, E., 1950. Growth, $14: 295-325$.

13) Hakman, I., L. C. Fowke, S. V. Arnold, T. Eriksson, 1985. Plant Sci., 38: 53-59.

14) Hakman, I., L. C. Fowke, 1987. Can. J. Bot., 65 : 656-659.

15) Murashige, T., F. Skoog, 1962. Physiol. Plant., 135: 473-497. 
16) John, A., K. J. Webb, 1987. In "Cell and Tissue Culture in Forestry, Vol. 3" (ed. by J. M. Bonnga, D. J. Durzan), p. 30-41.

17) Tanaka, R., H. Ikeda, 1983. Jpn. J. Genet., 58: 65-70.

18) Syōno, K., 1965. Plant Cell Physiol., $6: 403-419$.

19) Murashige, T., R. Nakano, 1965. Am. J. Bot., 52: 819-827.

20) Yokoyama, T., M. Takeuchi, 1977. Phytomorphology, 15: 273-275.

《和文要約》

\section{ヒョクヒバ小枝片から得られた幼芽形成組織の誘導と継代培養}

横山奉三郎*, 新井正善, 竹内正幸

埼玉大学理学部生体制御学科

* 現在：乙どむ動物自然公園

サワラの園芸品種であるいとひば，別名ひよくひばの小枝の小片を器内培養し，カルスの増殖に伴い 不定芽原基の分化も同時に起こる一種の組織培養系を得た．乙の系を代培養することにより，長期間不 定芽原基の分化能力を失うことなくこの系を維持することができた．この系の誘導には $1 / 2$ 亿希釈した ムラシゲ・スクーグの培地にビタミン, 18 種のアミノ酸, $1 \mathrm{mg} / l$ ベンジルアデニンと $0.3 \mathrm{mg} / \mathrm{l}$ イン ドール酶酸を含んだ培地が最適であった．継代培養にあこの培地が適していた．不定芽原基を分離して の培地からベンジルアデニンを除いてインドール酪酸やナフタリン酶酸を含んだ培地上で培養すると幼 苗に成長した. この幼苗には鱗片葉ではなく針葉が発達した. 